\title{
К.В. Ферфецька
}

\section{КЛІНІЧНІ ОСОБЛИВОСТІ ПЕРЕБІГУ ХРОНІЧНОГО ПАНКРЕАТИТУ, ПОСДНАНОГО 3 ОЖИРІННЯМ ТА ЦУКРОВИМ ДІАБЕТОМ ТИПУ 2}

Вищий державний навчальний заклад України «Буковинський державний медичний університет», м. Чернівці

Резюме. Обстежено 30 хворих на хронічний панкреатит та 55 хворих на хронічний панкреатит, поєднаний $з$ ожирінням та цукровим діабетом типу 2. Проаналізовано особливості клінічного перебігу хронічного панкреатиту в обстежених хворих. Виявлена різниця в інтенсивності, локалізації та іррадіації абдомінального

Вступ. Підшлункова залоза (ПЗ) - це практично єдиний орган, який завдяки поєднанню зовнішньосекреторної та ендокринної функцій бере участь у багатьох фізіологічних процесах, починаючи 3 травлення і закінчуючи процесами адаптації [3,7]. ПЗ виробляє гормони, що мають діаметрально протилежну дію, та водночас взаємодіючи між собою та з іншими гормонами, підтримують ендокринну систему в стані динамічної рівноваги $[12,13]$. Тому, будь-які патологічні і навіть функціональні зміни в ній завжди призводять до різного ступеня вираженості метаболічних порушень [14, 15].

Визнано, що хронічний панкреатит (ХП) це хронічне поліетіологічне запальне захворювання тканини ПЗ із вогнищевими, сегментарними або дифузними, дегенеративними та деструктивними змінами паренхіми, із розвитком фіброзу та порушенням іiї екзо- та ендокринної функції [5]. Як самостійний етіологічний фактор розвитку ХП останнім часом стали розглядати ожиріння $[1,8]$. Гіперліпідемія, що виникає при ожирінні, $\epsilon$ фактором, який сприяє жировій інфільтрації ПЗ і розвитку панкреатиту[16]. Водночас проведені дослідження підтверджують, що для виникнення панкреатиту на тлі гіперліпідемії необхідна вторинна дія на ПЗ алкоголю або деяких лікарських засобів, чи декомпенсація паралельно перебігу цукрового діабету (ЦД) [17]. Метаболічний синдром (MC), що формується при ожирінні, сприяє перенасиченню жовчі холестерином і утворенню мікролітів, у т. ч. у жовчному міхурі. Постійне виділення мікролітів у жовчовивідну протоку може призводити до папіліту, ретроградного підвищення тиску в протоках, повторних епізодів загострення панкреатиту з пошкодженням екзокринної та ендокринної тканин, розвитку хронічного обструктивного панкреатиту 3 подальшою деструкцією острівців П3 та розвитком ЦД [2, 4, 9]. Отже, незважаючи на певну кількість публікацій щодо ролі ожиріння та ЦД у перебігу ХП, дана проблема потребує подальшого вивчення.

Мета дослідження. Проаналізувати особливості клінічного перебігу хронічного панкреатиту, поєднаного $з$ ожирінням та цукровим діабетом типу 2. болю, симптомах диспепсичного синдрому та проявах зовнішньосекреторної недостатності підшлункової залози, результатів пальпації.

Ключові слова: хронічний панкреатит, ожиріння, цукровий діабет типу 2 , клінічні особливості.

Матеріал і методи. У дослідження включено 85 хворих на ХП, віком від 27 до 71 року. Усіх обстежених розподілили на дві групи, репрезентативних за чисельністю, віком та статтю (I група - 30 хворих на ХП без супутньої патології; II група - 55 хворих на ХП, поєднаний з ожирінням та ЦД типу 2).

У дослідження увійшли також 40 практично здорових осіб, вік та стать яких суттєво не відрізнялися від цих характеристик хворих на ХП. Серед обстежених переважали жінки - 54 (63,5 \%) та 31 чоловік $(36,5 \%)$.

За даними анамнезу встановлено, що в більшості хворих давність ХП складала 5-14 років, захворювання загострювалося один-два рази на рік, у зв'язку з чим їм призначали стаціонарне лікування. У 42 пацієнтів (49,4 \%) виявлено супутню гастроентерологічну патологію (хронічний некалькульозний холецистит, хронічний гастродуоденіт) та ішемічну хворобу серця - у 30 (35,3\%).

Діагноз ХП верифікований згідно з наказом MO3 України №638 від 10.09.2014 р. [11]. Діагноз ЦД 2-го типу встановлювався згідно з наказом МО3 України №1118 від 21.12.2012 р. [10]. Усім пацієнтам проведено ретельне обстеження 3 використанням загальноприйнятих клінічних, лабораторних та інструментальних досліджень. Для діагностики ХП проводилося визначення активності $\alpha$-амілази в сироватці крові (амілокластичним методом за Каравеєм) та діастази сечі, зовнішньосекреторну функцію ПЗ оцінювали за вмістом жиру в калі (за методом Ван де Крамера) та даними копрограми (оцінка проводилась за методами Л. В. Козловської та О. Ю. Ніколаєва). Біохімічне дослідження крові включало визначення глюкози крові натще, активності аланінамінотрансферази (АЛТ), аспартатамінотрансферази (АСТ), лужної фосфатази (ЛФ), вмісту загального білірубіну, протеїнограми, коагулограми.

Структурні зміни ПЗ виявляли за допомогою ультрасонографічного дослідження («Aloka» SS630 (Японія)).

За необхідності хворим призначали гастродуоденофіброскопію (ГДФС), рентгенологічне дослідження шлунка та дванадцятипалої кишки. 
Проводили антропометричне обстеження: визначали зріст (м), масу тіла (кг), обчислювали індекс маси тіла (IMT, кг/м²) за формулою Кетле.

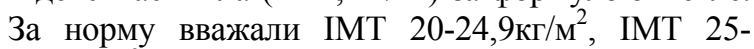
$29,9 \kappa г / \mathrm{M}^{2}$ оцінювали як надлишкову вагу, IMT

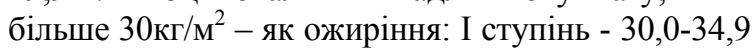

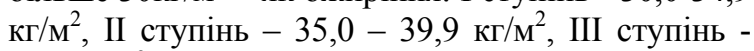
$\geq 40$ кг/м² $[6,8]$. Для оцінки абдомінального типу ожиріння визначали окружність талії, оскільки цей показник більшою мірою корелює з абсолютною кількістю вісцерального жиру, ніж відоме співвідношення окружності талії / окружності стегон. ОТ вимірювали в положенні стоячи на середині відстані між нижнім кінцем грудної клітки та гребенем клубової кістки по середньоаксилярній лінії. Ожирінням за абдомінальною формою вважали, якщо величини окружності талії були $\geq 94$ см для чоловіків, а для жінок $-\geq 80 \mathrm{~cm}$.

Статистична обробка отриманих даних виконувалася на персональному комп'ютері «ViewSonic» 3 використанням стандартних пакетів програм Microsoft Excel та за допомогою комп'ютерних програм Statistica for Windows версії 8.0 (Stat Soft inc., США).

Результати дослідження та їх обговорення. Проаналізувавши основні скарги пацієнтів, дані фізикального дослідження та результати додаткових методів обстеження, виявлено, що перебіг ХП визначається формуванням та прогресуванням таких синдромів: больового (у 88,2 \% пацієнтів), диспепсичного (у 67,4 \% пацієнтів), зовнішньосекреторної недостатності ПЗ (45,9 \% пацієнтів). Больовий синдром характеризувався періодичними ниючими, тупими болями, інколи оперізувального характеру з іррадіацією в ліве та праве підребер'я, спину, які посилювалися в положенні хворого на спині та зменшувалися в сидячому положенні та нахилі тулуба уперед.

Оцінка антропометричних даних показала, що у 26 пацієнтів I групи (86,7 \%) була нормальна маса тіла, у чотирьох (13,3\%) - дефіцит маси тіла. Слід відзначити, що дефіцит маси тіла частіше спостерігався в чоловіків, які підтверджували зловживання алкоголем. У пацієнтів II групи спостерігалося ожиріння I ст. - у 32 осіб (58,2\%), ожиріння II ст. - у 16 (29,1 \%) та ожиріння III ст. - у 7 (12,7 \%) пацієнтів.

Основною скаргою пацієнтів обох груп був абдомінальний біль. У I групі біль більш інтенсивний, у 20 пацієнтів (66,7 \%) частіше реєструвався нападоподібний характер болю та в 10 пацієнтів (33,3 \%) він був постійним. Щодо II групи пацієнтів, то скарги на біль постійного характеру виявлено у 38 пацієнтів (69 \%), нападоподібний больовий синдром відмітили лише 17 осіб (31\%).

Серед пацієнтів I групи переважала іррадіація болю за типом «повного пояса» - 14 (46,7 \%), дещо рідше спостерігався біль за типом «лівого напівпояса» - $9(30 \%)$ та за типом «правого пояса» - 7 (23,3 \%) осіб. Пацієнти II групи частіше скаржилися на біль за типом «лівого напівпояса» - $\quad 37(67,3 \%),(\mathrm{p}<0,05)$, за типом «повного поя- ca» - $13(23,6 \%)(\mathrm{p}<0,05)$ та за типом «правого пояса» - 5(9,1 \%), $(\mathrm{p}<0,05)$. У 5,3\% пацієнтів спостерігалася іррадіація болю в ліве плече та в 4,8 \% - у ліву ключицю.

Більша частина хворих пов'язувала появу больового синдрому 3 порушенням дієти (споживання жирної, смаженої їжі, алкоголю та газованих напоїв, свіжої здоби).

При загостренні ХП у 67,4 \% пацієнтів переважав диспепсичний синдром із зниженням або відсутністю апетиту, відрижкою, нудотою, блюванням, що не приносило полегшення.

Пацієнти I групи частіше скаржилися на нудоту - у 21 (70\%), зниження апетиту - у 14 $(46,7 \%)$, метеоризм - у 11(36,6\%), почастішання випорожнення - у 16 (53,3\%)осіб. У пацієнтів II групи переважали симптоми кишкової диспепсії у вигляді метеоризму - (у 50-91 \%), бурчання (35-63,6 \%), нестійких випорожнень - у 19 (34,5 \%), також спостерігалася нудота - у 42 (76,3\%), відрижка - у 28 (49\%) осіб.

Клінічні прояви зовнішньосекреторної недостатності ПЗ (панкреатичні проноси по два-три рази на добу, виділення кашкоподібного 3 жирним блиском калу із залишками неперетравленої їжі, зниження маси тіла, прояви гіповітамінозу) траплялися рідко (у 9-16,3 \% пацієнтів II групи), значно частіше симптоми екзокринної недостатності ПЗ виявляли в пацієнтів I групи (у 17$56,6 \%$ осіб).

При поверхневій пальпації на чутливість або болючість у проекції ПЗ вказували 32 пацієнти (37,6 \%), а при глибокій пальпації - всі обстежені. Болючість у зоні Шоффара спостерігалася в 16 осіб (53,3\%) I групи та в 30 осіб (54,5\%) II групи. Рідше виявлялася болючість у зоні Губергріца-Скульського: у 8 осіб (26,7 \%) I групи та у 23 осіб $(43,6 \%)$ II групи $(\mathrm{p}<0,05)$. Крім того, в обстежених виявлені додаткові об'єктивні симптоми: болючість у точці Дежардена переважала в пацієнтів I групи - $16(53,3 \%)(\mathrm{p}<0,05)$ та в точці Мейо-Робсона в пацієнтів II групи - 24 (43,6 \%) $(\mathrm{p}<0,05)$ обстежених.

\section{Висновки}

1. Абдомінальний біль при хронічному панкреатиті, поєднаному з ожирінням та цукровим діабетом типу 2 частіше був постійним та менш інтенсивним, порівняно з групою осіб при ізольованому хронічному панкреатиті; переважала іррадіація за типом «лівого напівпояса» та за типом «повного пояса».

2. Диспепсичний синдром спостерігався рідше в пацієнтів за поєднання хронічного панкреатиту 3 ожирінням та цукровим діабетом типу 2 , переважали симптоми кишкової диспепсії; клінічні прояви зовнішньосекреторної недостатності підшлункової залози розвивалися частіше при ізольованому хронічному панкреатиті - у 17 (56,6 \%) осіб, а при поєднанні хронічного панкреатиту 3 ожирінням та цукровим діабетом типу 2 лише у $9(16,3 \%)$ осіб. 
3. Найбільша пальпаторна болючість виявлена в зоні Шоффара у пацієнтів обох груп, хоча в 43,6 \% хворих на хронічний панкреатит, поєднаний $з$ ожирінням та цукровим діабетом типу 2 , спостерігалася болючість переважно в зоні Губергріца-Скульського.

Перспективи подальших досліджень. Перспективи досліджень полягають у подальшому виявленні лабораторних та інструментальних особливостей хронічного панкреатиту, поєднаного 3 ожирінням та цукровим діабетом типу 2, розробці нових методів діагностики та лікування зазначеної патології.

\section{Література}

1. Бондаренко О.А. Клинические особенности хронического панкреатита, протекающего на фоне ожирения / О.А. Бондаренко // Вестн. клуба панкреатол. - 2011. № 3 (12). - C. 31-33.

2. Влияние болевого синдрома на качество жизни у пациентов с заболеваниями поджелудочной железы / Г.А. Новиков, М.А. Силаев, Селиванова [и др.] // Паллиатив. мед. и реабилитация. - 2006. - № 4. - С. 5-7.

3. Губергриц Н.Б. Клиническая панкреатология / Н.Б. Губергриц, Т.Н. Христич. - Донецк: ООО Лебедь, 2000. $-416 \mathrm{c}$.

4. Губергриц Н.Б. Метаболическая панкреатология / Н.Б. Губергриц, А.Н. Казюлин. - Донецк : Лебедь, 2011. $-464 \mathrm{c}$.

5. Денисюк B.I. Доказова внутрішня медицина: Таємниці, стандарти діагностики та лікування / B.I. Денисюк, О.В. Денисюк. - Вінниця: ДП МКФ, 2006. - 704 с.

6. Костіна В.М. Метаболічний синдром : методи діагностики та реабілітації / В.М. Костіна, В.О. Зюзін, Т.М. Зінченко // Наук. праці. - 2011. - Т. 52. - С. 76-78.

7. Лопаткина Т.Н. Хронический панкреатит / Т.Н. Лопаткина // Нов. мед. ж. - 1997. - № 2. - С. 7-11.

8. Ожирение. Глобальные Практические Рекомендации Всемирной Гастроэнтерологической Организации / Jamos Toouli, Michael Fried, Aamir Ghafoor Khan[et al.] // World Gastroenterology Organization, 2009. C. 42 .

9. Ткач С.М. Практические подходы к диагностике хронического панкреатита / С.М. Ткач // Сучас. гастроентерол. - 2013. - № 1 (69). - С. 136-138.

10. Уніфікований клінічний протокол первинної та вторинної (спеціалізованої) медичної допомоги «Цукровий діабет 2-го типу». - Наказ Міністерства охорони здоров'я від 21.12.2012 №1118. - 56 с.

11. Уніфікований клінічний протокол первинної, вторинної (спеціалізованої) медичної допомоги та медичної реабілітації - Хронічний панкреатит. - Наказ Міністерства охорони здоров я від 10.09.2014 року № 638. $34 \mathrm{c}$.

12. Ферфецька К.В. Роль метаболічного синдрому у розвитку хронічного панкреатиту (огляд літератури) / К.В. Ферфецька, О.І. Федів // Бук. мед. вісник. - 2013. - Т. 17, № 2 (66). - С. 174-178.

13. Христич Т.Н. Роль поджелудочной железы (нейроэндокринной системы) в патогенезе метаболического синдрома / Т.Н. Христич, Т.Б. Кендзерская, 3.А. Мельничук // Сучас. гастроентерол. - 2004. - № 1. - C. 10-16.

14. Христич Т.Н. Эндокринные нарушения как этиологический фактор развития панкреатита / Т.Н. Христич, Т.Б. Кендзерская // Consilium Medicum. Приложение. 2008. - № 2. - C. 37-41.

15. Quality of life in patients with endoscopy-negative heartburn: reliability and sensitivity of disease-specific instruments / N.J. Alley, S. Fullerton, O. Unghard [et al.] // Am. J. Gastroenterol. - 2001 [Електронний pecypc] : 96:1998-2004. doi: 10.1111 /j. 1572-0241.2001.03932.

16. Sristava G. Hyperlipidaemic pancreatitis in pregnancy / G. Sristava, N. Rahman, D. Elsandabesee // J. Obstet. Gynecol. - 2010. - Vol. 30, № 1. - P. 59-60.

17. Blomgren K.B. Obesity and treatment of diabetes with glybunde may both be risk factors for acute pancreatitis / K.B. Blomgren, A. Sandstron // Diabetes Care. - 2002. Vol. 25, № 2. - P. 298-302.

\section{КЛИНИЧЕСКИЕ ОСОБЕННОСТИ ТЕЧЕНИЯ ХРОНИЧЕСКОГО ПАНКРЕАТИТА, СОЧЕТАЮЩЕГОСЯ С ОЖИРЕНИЕМ И САХАРНЫМ ДИАБЕТОМ ТИПА 2}

\section{Е.В. Ферфецкая}

Резюме. Обследовано 30 больных хроническим панкреатитом и 55 больных хроническим панкреатитом, сочетающегося с ожирением и сахарным диабетом типа 2. Проанализированы особенности клинического течения хронического панкреатита у обследованных больных. Выявлено различие в интенсивности, локализации и иррадиации абдоминальной боли, симптомах диспепсического синдрома и проявлениях внешнесекреторной недостаточности поджелудочной железы, результатов пальпации.

Ключевые слова: хронический панкреатит, ожирение, сахарный диабет типа 2, клинические особенности.

\section{CLINICAL FEATURES OF CHRONIC PANCREATITIS, COMBINED WITH OBESITY AND TYPE 2 DIABETES}

\section{K.V. Ferfetska}

Abstract. The study involved 30 patients with chronic pancreatitis and 55 patients with chronic pancreatitis, combined with obesity and type 2 diabetes analyzed the clinical course of chronic pancreatitis in patients. We observed difference in the intensity, location and irradiation of the abdominal pain, dyspeptic symptoms and syndrome manifestations of exocrine pancreatic insufficiency, the results of palpation.

Key words: chronic pancreatitis, obesity, diabetes type 2, clinical features.

Higher State Educational Institution of Ukraine "Bukovinian State Medical University” (Chernivtsi) 